\title{
Da excitação à multiplicação: imagens sadomasoquistas e fetichistas de Bizarre
}

Resumo: Tomando como corpus de análise a revista sadomasoquista e fetichista norteamericana Bizarre, editada entre 1946 e 1959 por John Willie, o presente artigo busca refletir sobre a relação entre o conteúdo da publicação e seus leitores, evidenciada sobretudo nas páginas de suas seções de correspondência. Após uma breve apresentação das práticas e da rede agrupada sob a sigla BDSM, buscaremos, nas páginas de Bizarre, diferentes modulações de agência de imagens, objetos e textos e seus efeitos sobre práticas, corpos e desejos sexuais tidos como 'desviantes'. Tais modulações serão divididas a partir das ideias de excitação, imaginação, identificação e multiplicação, a partir das quais, serão esboçados debates com teorias sobre o fetichismo, a agência das imagens e a formação identitária.

Palavras-chave: fetichismo, sadomasoquismo, Bizarre, agência, imagem.

Na seção de cartas do $22^{\circ}$ número da revista Bizarre, publicado em 1957, o leitor V.M. afirma que através das edições anteriores desta revista percebeu que sempre tivera uma sensação agradável ao ver mulheres amarradas, no cinema ou em revistas, mas nunca tinha pensado muito nisso. ${ }^{1}$ Ele não sabia que tanta gente tinha prazer em ver mulheres indefesas. Depois do contato com a revista e de uma experiência pessoal recente, V.M. passa a amarrar em cordas, com certa frequência, sua mulher, que consente e gosta da atividade. É difícil saber se V.M. e sua esposa jamais teriam começado a praticar a amarração com fins eróticos (bondage), caso não tivessem entrado em contato com Bizarre, mas é claro que a revista teve um papel importante nesse movimento, agiu como parte de um gatilho complexo que detonou uma mudança na vida sexual do casal.

A carta de V.M. não se destaca das publicadas ao longo das 26 edições de Bizarre entre 1946 e 1959: como este, há centenas de relatos sobre como o conteúdo da revista

\section{(c) (1)}

Esta obra está sob licença Creative Commons.

${ }^{1}$ Agradeço a Carlos Fausto, Raphael Bispo, Eduardo Viana Vargas e Raquel Freire de Andrade e às pareceristas anônimas por sugestões essenciais para o presente artigo. Como de praxe, quaisquer problemas no conteúdo deste artigo são de minha inteira responsabilidade. 
teve efeitos sobre o erotismo praticado, pensado e desejado por seus leitores. Talvez por isso a publicação - editada, escrita, ilustrada e distribuída de modo quase artesanal pelo australiano John Willie ${ }^{2}$ - seja hoje considerada um marco na história do fetichismo sexual, uma influência essencial para entendermos como o BDSM tornou-se o que é. Segundo Robert Bienvenu II, "apesar da pequena distribuição de Bizarre, através de sua revista e de seus contatos pessoais, Coutts exerceu uma influência tremenda no desenvolvimento do Estilo de Fetiche Americano" (BIENVENU II, 1998, p. 100).

Os textos e ilustrações de Willie foram importantes para constituir o repertório imagético dessa rede, ajudaram em sua tessitura. Se assim é, cabe interrogar: como esses desenhos, fotos e escritos conseguiram ajudar a criar e alterar o coletivo que hoje os tem como relíquias e que observa o editor como uma espécie de gênio? Que movimento provocaram? O que causaram nos corpos dos que os observaram? Para responder, volto-me para a análise das revistas, procurando diálogos com seus leitores, evidenciados nas seções de correspondência. Posteriormente, poderemos partir da ideia de Bizarre como um simples marco histórico em direção à Bizarre como um objeto com agência no mundo. O tema da agência de objetos tem ganho repercussão na Antropologia, desde os anos 1990, - ver, por exemplo. Alfred Gell (1998) e Bruno Latour (2002) - mas parece ter sido pouco aplicado ao BDSM , ao fetichismo sexual e à pornografia. No que segue, buscarei descrever modos de relações específicas entre imagens, textos, leitores e autores.

\section{BDSM}

O acrônimo BDSM é formado pelas palavras inglesas Bondage, Domination e SadoMasochism e diz respeito a um agrupamento social que se articula em torno de práticas sexuais consideradas heterodoxas ou desviantes, especialmente sadomasoquistas - práticas que envolvem conjunção de dor física e/ou psíquica com o prazer erótico - e fetichistas - o uso de determinados materiais, objetos ou partes do corpo, como espartilhos, couro ou pés, como fontes de prazer e desejo sexual. O BDSM funciona como termo guarda-chuva sob o qual múltiplas possibilidades de interesses e práticas eróticas se unem. Além das práticas, o BDSM se define por seus praticantes, trata-se de uma rede, ou, em termos de seus adeptos, de uma 'cena', um agrupamento que se articula através de mídias (revistas, sites, filmes etc.) e espaços (clubes, festas, encontros etc.) diversos. Nem todo sujeito considerado sádico, masoquista ou fetichista será considerado participante da cena-apenas aqueles ativamente ligados a ela -, o que não impede que uma pessoa considere o BDSM parte relevante de sua vida sexual, mesmo isolada da rede. Isso significa - conforme argumenta Margot $D$. Weiss (2006), seguindo Judith Butler (1990) - que o BDSM cai nas frestas entre um conjunto de práticas e de potenciais identidades: tende a ser mais entendido como um 'fazer' do que como um 'ser', as pessoas que fazem parte do coletivo são descritas mais como 'praticantes' do que como 'BDSMistas', de forma que o BDSM, em geral, esquiva-se de aparecer como uma identidade sexual defendida politicamente na arena pública. Entretanto, para aqueles mais profundamente envolvidos na cena, o BDSM pode ser descrito como um 'estilo de vida', o que significa, como parte do dispositivo da sexualidade (Michel FOUCAULT, 1988), ser mais entendido como definidor de uma subjetividade sexualizada do que uma prática como, digamos, o sexo oral.

\footnotetext{
${ }^{2}$ John Willie é pseudônimo de John Coutts. Refiro-me a ele por Willie ou J.W., como assinava seus trabalhos. Para um panorama da influência do artista, cf. Robert Bienvenu II, 1998, p. 86-101. Além dos leitores, colunistas e colaboradores como Sylvia Soulier, Paula Sanchez, lbitoe aparecem na revista, mas não consegul identificar de quem são pseudônimos ou se seriam personagens.
} 
Sobretudo a partir do pós-guerra e, em especial, no eixo Norte-Atlântico, o BDSM contemporâneo forma-se e, até certo ponto, institucionaliza-se, criando uma 'rede' ou 'cena' de praticantes e um 'estilo', 'tradição' ou 'estética' particulares. As histórias relativamente canônicas desse movimento apontam Bizarre como particularmente importante para tal consolidação (BIENVENU II, 1998). Bizarre destaca-se dentre as publicações eróticas de seu tempo pelo pioneirismo na maneira de abordar os fetiches e o sadomasoquismo: em comparação com os periódicos que tratavam desses temas - sobretudo os publicados na Inglaterra ao menos desde 1861, que atingiam principalmente o mundo anglo-saxão e europeu, como Englishwomans' Domestic Magazine, Photo Bits e London Life -, a revista de John Willie era decididamente mais ousada em seus textos e imagens. Logo, eram necessários subterfúgios para burlar as rígidas leis antiobscenidade norte-americanas então vigentes, de modo que Bizarre era anunciada como uma revista "para escravos da moda" - suas matérias dedicadas às roupas, materiais e acessórios fetichizados faziam-se passar por meros artigos sobre vestimentas. Outra estratégia irônica para burlar a censura consistia em colocar textos e imagens de sabor sadomasoquistas em um contexto que falasse sobre educação, disciplina e punição, ou legendá-las com a frase "Não deixe que isso aconteça com você! Aprenda jiu-jitsu, a arte da autodefesa." De fato, parte do impulso que levou Willie a editar sua própria revista foi sua visão de que revistas como London Life (para a qual chegou a contribuir) eram 'recatadas'. (BIENVENU II, 1998, p. 91). Em Bizarre apareceria uma variedade maior de práticas eróticas do que em suas antecessoras, ilustradas de maneiras mais explícitas.

Cabe sublinhar que a consensualidade é tida como fator decisivo nas relações traçadas sob a rubrica do BDSM: ao menos dentro da 'cena', atos sexuais fetichistas e sadomasoquistas devem ser guiados por uma ética resumida pela sigla SSC - São, Seguro e Consensual. ${ }^{3} \mathrm{Na}$ época de Bizarre, nenhum dos dois acrônimos existia, mas o germe de ambos se faz visível, de modo que cabe um breve desvio. O discurso sobre o SSC é acompanhado de mecanismos específicos, como safewords (palavras que permitem que o dominado interrompa o ato), workshops para que acidentes não ocorram, etc. O SSC é levantado por seus praticantes como argumento contra a ideia de que seus sadismos poderiam ser lidos como formas de violência de facto (sexual ou outra): se todos os envolvidos são adultos que, de forma sã, concordam com os atos e minimizam os riscos envolvidos, a hierarquia entre dominador e dominado, o emprego da força física e mesmo da tortura psicológica não implicariam em agressão ou opressão. É altamente rechaçado, nas mídias BDSM ałuais, como já era em Bizarre, impor práticas sexuais sadomasoquistas a não adeptos. De acordo com a ativista lésbica pró-BDSM Pat Califia ${ }^{4}$.

A palavra-chave para entender o sadomasoquismo é fantasia. Os papéis, o diálogo, as roupas fetichistas e a atividade sexual são parte de um drama ou ritual. As participantes estão aumentando seu prazer sexual não causando danos ou prendendo uma à outra. [...] relações sadomasoquistas são em geral igualitárias [...] A subcultura sadomasoquista é um teatro no qual dramas sexuais podem ser representados (CALIFIA, 2000).

A defesa do BDSM por parte dos praticantes não resolve todos os seus problemas. A começar porque aquilo que Califia apresenta como fantasia ou teatralidade pode ser lido também como um jogo no qual há ganhadores ou perdedores, o que já torna o 'ritual' menos igualitário. (cf. FOUCAULT; James O'HIGGINS, 1983, p. 20-21).

${ }^{3}$ Bruno Zilli (2007) apresenta uma rica leitura do SSC a partir do BDSM brasileiro.

${ }^{4}$ Califia hoje se identifica como homem trans bissexual. Não sei dizer se mudou seu ponto de vista sobre o BDSM. 
Ademais, as fantasias atualizadas no BDSM não deixam de ter origem em desigualdades e opressões reais - de gênero, classe, orientação sexual, etc. Nas leituras críticas do BDSM, as performances sadomasoquistas seriam uma maneira de perpetuar tais violências na intimidade, enquanto seus defensores sublinham o potencial subversivo da teatralização. ${ }^{5}$ De fato, escrever sobre o sadomasoquismo é sempre adentrar num terreno pantanoso, amiúde tratado como metonímia ou paroxismo da violência de gênero. Ver, por exemplo, o fundamental ensaio de Simone de Beauvoir sobre Sade e a leitura feita por Judith Butler das implicações de "violência ética" (BEAUVOIR, 1955; BUTLER, 2005, p. 45; Lauren GUILMETTE, 2011).

Tentar dar conta das variadas posturas em relação ao tema exigiria um espaço de que não disponho no presente artigo, de maneira que não tomarei posição de forma contundente na controvérsia sobre se as práticas sadomasoquistas (e outras sexualidades dissidentes) seriam libertadoras ou conservadoras em relação a uma moral repressora ou a estruturas de poder-saber-prazer. A discussão, que toma sua forma mais candente no contexto do feminismo antipornografia dos anos 1980, é rebatida pela emergência do sadomasoquismo lésbico e por autoras ditas pro-sex, e continua viva no presente, ganhando novo fôlego a partir de teorias queer que elaboram conceitos como "contrassexualidade" e "pós-pornô", em busca de formas que ultrapassem o identitário para discutir - e produzir - textos, imagens e vídeos que ultrapassam o binarismo e heteronormatividade da pornografia dita tradicional. ${ }^{6}$

Apesar de não ser o foco do artigo, a análise de Bizarre, espero, trará elementos para entender que o BDSM refrata de múltiplas maneiras relações e hierarquias de classe, gênero, raça; promove associações possivelmente subversivas e criativas, mas eventualmente pode ser reacionário e conservador. Como veremos, em Bizarre, a esmagadora maioria dos corpos são femininos, brancos e magros, e se há abertura no que tange ao gênero, o mesmo não ocorre em relação a outros pontos. Não é o objetivo aqui defender ou atacar Bizarre. A publicação certamente estava ancorada em pontos de vista prevalentes no contexto espaço-temporal em que se insere - era uma revista para euroamericanos brancos, de classe média, lutando, nas décadas de 1940 e 1950, contra certos aspectos da moral puritana estadunidense, mas abraçando outros. Uma breve incursão na questão racial, ao fim do artigo, buscará trazer ao primeiro plano tal ponto, que permanece implícito na maioria do texto. Pois o interesse central aqui é de outra ordem: apesar de tangenciar uma discussão sobre poder, o foco é certas modalidades de agência envolvidas nas relações que os leitores estabeleceram com a revista. O presente artigo é, sobretudo sobre imagem e excitação, e pretende-se, antes de tudo, descritivo: seu objetivo é analisar relações e reações ao conteúdo de Bizarre.

É fundamental a forte participação dos leitores na construção do conteúdo de Bizarre. Logo nos primeiros números surge uma gorda seção de correspondência, que aos poucos vai tomando mais e mais espaço, chegando a haver três edições exclusivamente dedicadas aos materiais recebidos pelo correio. Nesse espaço, leitores e leitoras - protegidos por pseudônimos ou iniciais - comentavam o conteúdo dos exemplares anteriores, descreviam experiências, fantasias e desejos eróticos, incentivavam mais trechos sobre certos assuntos e criticavam outros, enviavam fotos, desenhos e poemas de sua autoria ou que consideravam inspiradores. Davam vida à revista. Algumas histórias narradas na seção

${ }^{5}$ A título de exemplo de tal controvérsia, ver o debate entre bell hooks (1996) e Andrea Dworkin (1997). ${ }^{6}$ Esses debates estão apresentados em artigos de pesquisadoras como Maria Filomena Gregori (2004), que faz uma exposição do debate no feminismo estadunidense; María Elvira Díaz-Benítez (2010, 2015), que oferece uma reflexão matizada e interessante a partir da pornografia produzida no Brasil; e Erica Sarmet (2014), que busca dar sentido ao pós-pornô queer na América Latina.

4 Revista Estudos Feministas, Florianópolis, 26(2): e 43211 
de correspondência de Bizarre eram tão incríveis que o editor chegou a ser acusado de forjar o conteúdo das cartas, fazendo suas fantasias passarem por palavras de leitores. Willie respondia que infelizmente sua criatividade não era tão imensa a ponto de torná-lo capaz de criar relatos tão diferentes entre si, sobre temas tão diversos, e em estilos de escrita tão variados. Chegou a publicar fotos com pilhas de cartas para provar sua veracidade.

Como os debates acima mencionados sublinham a representação do corpo - em particular do corpo feminino objetificado - na pornografia, este é um tema forte dentro dos estudos de gênero, feministas e queer. Atualmente, a explosão do BDSM e da pornografia na internet tem gerado um volume crescente - ainda a ser cartografado teórica e metodologicamente - sobre como a figura do produtor (ou cadeia de produção) e do consumidor (ou receptor) de erotismo se confundem e se remodelam a partir das novas tecnologias. ${ }^{7}$ Observar Bizarre ajuda a compreender como tal confusão já se prefigurava anteriormente, nesse contexto onde teatralidade e segredo se encontram, talvez por um complexo mecanismo. Mecanismo este que pode fazer da teatralização de um erotismo semissecreto, algo crescentemente importante para a vida privada daquele que abraça esse 'estilo de vida'8 Dedico-me então à análise das imagens contidas em Bizarre e de sua relação com as seções de correspondência, espaços de interação onde aqueles que supostamente seriam meros receptores tornam-se produtores e agem sobre o conteúdo da publicação. Para além das ideias de senso crítico e mediação, já tão debatidas pela teoria da comunicação, veremos, no que segue, como a pragmática do gosto toma outros contornos quando a agência de não humanos (como imagens) entra na equação.

\section{Excitação}

Podemos dividir as imagens de Bizarre em quatro grupos: caricaturas, histórias em quadrinhos, ilustrações e fotografias. As duas primeiras, em geral de tom mais cômico e leve, são pouco referidas nas seções de cartas de Bizarre. Logo, não nos concentraremos nelas. Nas fotografias e ilustrações está o sabor predominante da publicação. Em sua maioria, figuram mulheres - em máscaras, saias-funil, espartilhos, salto-alto, botas longas, roupas de couro, náilon, borracha, látex... Muitas mulheres amarradas em cordas, acorrentadas, presas, torturadas. Quase sempre posando, de corpo inteiro, sozinhas sobre fundo neutro, em postura de dominação ou de submissão. Imagens de ação são mais raras, à exceção daquelas envolvendo atos de apertar o espartilho, amarrar cordas etc. Aparecem também mulheres no ato de imobilizar, pisar, prender, submeter homens ou mulheres. Imagens nas quais o corpo não aparece por inteiro em geral focam um fragmento específico, como o sapato, o pé, a máscara, a algema etc.

Desses corpos e daquilo que os cerca emerge a primeira e mais óbvia ação sobre leitores, a excitação, provocando desejo ou furor erótico. Em VIII:589 lê-se: "Tenho certeza que leitores apreciarão a gentileza daqueles que mandaram as fotografias para você, de modo que possamos compartilhar de seu prazer". O leitor Mac afirma: "o belamente escrito e primorosamente fotografado artigo de Sylvia Soulier é puro deleite para cada amante de

\footnotetext{
${ }^{7}$ Para ficar apenas em alguns exemplos brasileiros contemporâneos, cf. Díaz-Benítez,(2010); Jorge Leite Jr., (2009, 2012); Sarmet (2014); Mariana Rost (2016).

${ }^{8}$ Uma análise da obra de Wilma Azevedo no Brasil dos anos 1980 poderia traçar rotas semelhantes. De acordo com Regina Facchini e Sarah Machado (2013, p. 200), os escritos ficcionais eróticos de Azevedo, produzidos em contato com praticantes do BDSM que se comunicavam via classificados "davam voz às fantasias e às práticas dos integrantes desse meio". Veja também Anne McClintock (2003) e Marcelle Silva; Antonio Paiva (2014).

9 Uso a seguinte notação para referências às revistas: numerais latinos para edição e arábicos para página. VI:6 indica Bizarre 6, p. 6. Todas se referem à reimpressão em dois volumes editada por Eric Kroll (WILLIE, 1995)
} 
botas e sapatos de salto alto" (XV/XVl:90). O que excita os leitores não é meramente os elementos do erotismo 'tradicional', como a forma do corpo ou os olhares provocantes das modelos. Ainda que afirmem, por exemplo, que os salto altos elevam o tamanho da perna a proporções mais graciosas, que quanto mais alto o salto, menor e mais belo o pé (l:13); ou que exaltem a elegância e as curvas moldadas pelo espartilho e a beleza da borracha brilhante (IX:64), há mais. O fotógrafo fetichista Eric Kroll, no prefácio da reedição de Bizarre, afirma que, sim, os espartilhos e salto altos têm seu charme, mas o excitante neles é o desconforto que causam em quem usa (Eric KROLL, 1995, p. 10). Em XIV:9, Sylvia Soulier afirma que as fotos que envia podem agradar a "alguns de seus leitores homens maliciosos, sempre atrás de ver uma menina em aflição ou desconforto." Blind Girl Fluff escreve um artigo ilustrado sobre máscaras e sua capacidade de causar cegueira, surdez, restrição, pressão, mistério (Vl:41-45). Há, de maneira geral, um "imenso entusiasmo pelo corpo amarrado, tanto visto quanto sofrido" (XXIII:24). Excitar-se com Bizarre seria excitar-se principalmente com o sofrimento, seja pelo gosto da sensação de dominação causada pela observação da situação de desamparo ou pela possibilidade de se colocar na situação de submissão. Em alguns casos a visão nem é necessária, apenas o desconforto: como na carta com desenho esquemático sobre como adaptar botas de cowboy para que tenham um salto-alto por dentro, invisível por fora (XXV:62).

A modulação mais comum de excitação sexual provocada por Bizarre é sadomasoquista, envolve relações erotizadas de dominação e submissão, passando pela dor física e pela constrição do corpo. Quase sempre a dor e a submissão necessitam de algum objeto para serem efetivadas - chicotes, piercings, cordas... Mas algumas imagens, como as de renda, borracha e couro, pouco ou nada possuem de sadomasoquistas. Entra em cena a modulação fetiche, excitação erótica por certos tipos de objetos ou materiais. Cartas sobre borracha nos ajudam a entender como se opera o entrelaçamento entre esse material e o prazer. Miss Mystery afirma que seu interesse na borracha está na sensação tátil, na textura do material em contato com os dedos, nos sons de estalido que produz. Diz: "apreciei muito as adoráveis fotos de roupas de borracha femininas na página 37, enviadas por J.H.W. É delicioso ver uma dama usando um par de botas de borracha, e um encantador, brilhoso casaco preto combinando." (X:62-64). S.P. afirma: "desde que me lembro, a visão, sensação e cheiro de borracha me excita muito além da imaginação de uma pessoa comum" (XVIII:30). Vemos uma erotização multissensorial de objetos e materiais, que variam de cigarros (VIII:25) a cabelos longos (V:25), passando por palhaços (XVII:59) e salto-altos. Na foto da contracapa de XIX um homem é pisado por uma mulher em capa e botas de borracha e luvas de couro. Fetichismo e sadomasoquismo, misturados ou isolados, são focos em Bizarre, mas a excitação ali não se limita a essas duas formas.

É preciso expandir a noção de excitação que venho usando, pois este movimento não se encerra em suscitar erotismo e lascívia, não se limita a estimular o desejo. Excitação significa também o ato de animar, mover, provocar, levar à ação. Usando o vocabulário latouriano, excitar é uma forma de 'fazer-fazer' (LATOUR, 2002) ${ }^{10}$. Penso na capacidade das imagens, dos objetos e dos textos de colocar os corpos em um estado de exaltação que pode provocar-lhes alterações, estimulá-los à agência, entrelaçando os elementos em movimentos que não possuem origens claras: o corpo excita-se com uma imagem criada por outro corpo, que por sua vez pode ter sido excitado por outra imagem baseada em outro corpo. E assim por diante.

\footnotetext{
${ }^{10}$ Assim, a noção de excitação aqui utilizada vai além daquela - genitalizada e reprodutiva - criticada por Paul Beatriz PRECIADO (2014, p. 23).
}

6 Revista Estudos Feministas, Florianópolis, 26(2): e43211 
A carta de V.M. nas primeiras linhas deste artigo vai ao encontro dessa ideia, e há outros tantos como ele: B.H. afirma que, após sua esposa ter visto a ilustração em XIV:33, disse que queria ser acorrentada, e ele passou a fazê-lo diariamente (XV/XVI:112). Em VII:40-43 Nikki conta como ela e uma colega costuraram vestidos baseados em uma indumentária desenhada por J.W. em III:40, a fim de usá-los em um baile; ficaram a noite inteira com chapéu de burro e braços amarrados atrás das costas, olhando para a parede, como que de castigo; foram alimentadas na boca e atraíram a atenção da maioria dos homens na festa. Em Bizarre há, inclusive,x uma seção 'faça você mesmo', na qual leitores ensinam, passo a passo, por vezes com esquemas, como fazer uma máscara de couro (XIII:37), como amarrar uma mulher (XXIl:4-10), como transformar saltos de 3" em saltos de 6" (XXII:26-29), como fazer botas que se pareçam com cascos de cavalo (XXV:38), como adaptar uma sapatilha de bailarina para manter os pés en pointe constantemente (XVII:45-48). Esta última adaptação uma leitora faz em casa, e em XX:43 são publicadas fotos suas usando as sapatilhas bizarras. A profusão de exemplos nos autoriza a pensar em Bizarre e em suas imagens como objetos dotados de agência, que fazem as pessoas fazerem coisas. Estes modos de fazer-fazer por vezes se dão através de sugestões diretas, porém na maioria dos casos são apropriações inesperadas das imagens: as ações resultantes dessas associações vão além das intenções dos criadores, que perdem o controle de suas criações ao serem superados por elas.

Obviamente, não quero dizer nem que Bizarre sozinha transformou centenas de leitores inocentes em 'pervertidos sexuais', nem que nas páginas da revista foram criadas modalidades completamente originais de fetiche. Mrs. L.H. afirma que já usava espartilhos, mas "lendo Bizarre, testei diversos outros instrumentos descritos por leitores [...] espero que os leitores continuem escrevendo sobre outros trajes e costumes bizarros que possamos experimentar" (XII:45). Havia, ao menos desde o século XIX, especialmente na Europa, outras revistas com tom parecido, além de produtores de roupas e sapatos fetichistas, clubes e círculos centrados nessas sexualidades heterodoxas. A ligação com publicações do passado aparece em desenhos ou artigos tirados de antigas edições de London Life e outras. Em V:30, um leitor envia um desenho encontrado em uma revista de 1880, de um aparelho de treinamento de postura que prende a cintura, os braços e o pescoço. Ele pede que J.W. faça uma versão nova da imagem, que aparecerá em VIl:39. Algumas edições depois aparece uma foto de uma leitora usando um aparelho muito parecido (XI:66) [fig. 1]. Uma cadeia de excitação busca o passado, alcança os leitores, passa por J.W. e atinge novos leitores.

O passado não se faz presente somente através da relação com publicações antigas: também as histórias de vida dos leitores são evocadas pelo conteúdo de Bizarre. A.E.H. (VII:47-48) exemplifica: "A impressão de uma memória de infância foi melhor avivada quando primeiro vi seu volume 2, página 8" (referindo-se a uma foto de uma mulher em botas de couro). A.E.H. segue descrevendo uma situação em sua infância quando foi levado a beijar as botas de couro de uma garota, e por fim afirma: "as fotos e artigos de suas deliciosas revistas reviveram o frêmito do incidente." Percebemos a inserção de Bizarre em outra cadeia temporal de excitação. Além da ligação com a 'cena' fetichista/SM mais ampla, a conexão diz respeito ao passado das pessoas, visto como constitutivo de sua personalidade e de seus gostos sexuais.

Notamos o papel da revista dentro de um projeto reflexivo de autopercepção e autocriação através da memória, especialmente memórias da infância: ela funciona como mecanismo reativador de sensações vividas em momentos tidos como cruciais nas biografias. Inúmeras cartas contêm relatos que remetem a histórias de infância e juventude, recheadas de eventos como filhos espancados pelos pais ou obrigados por governantas a 
se vestirem com roupas bizarras ou do sexo oposto. É evidente a operação do dispositivo da sexualidade, estimulador e construtor de subjetividades, qual descrito por Foucault (1988). Entretanto, ao contrário do que se poderia esperar, essas memórias marcadas pela 'dor' desses acontecimentos 'violentos' não colocam tais eventos como traumáticos - são considerados positivos. As pessoas deliciam-se em relembrar as atitudes de seus algozes, o desconforto e embaraço das situações que foram obrigadas a suportar. Valorizam tais episódios que despertaram o desejo pela dor, pela submissão ou pelo objeto tornado fetiche. E a conexão não se limita ao passado: os missivistas acreditam que seus relatos podem servir para excitar novos leitores, de modo que Bizarre serve como mediadora entre desejos e práticas sexuais passadas e futuras.

\section{Imitação?}

Até agora, não distingui fotografias e ilustrações. À primeira vista, as ilustrações em Bizarre - naturalistas, realistas - compartilham com fotos temas, composições e elementos. Mas há especificidades. Os desenhos de Willie assemelham-se a um estilo de imagem erótica popular nos EUA dos anos 30 aos 50: as pinups. São imagens aerografadas (garantindo impressão de tridimensionalidade) de mulheres em poses sensuais, representadas de corpo inteiro, em geral sozinhas, dirigindo o olhar ao espectador. Os fundos em geral são neutros, as cores vivas, o nível de nudez é padronizado, as expressões faciais sorridentes e um tipo de rosto e corpo é privilegiado: mulheres curvilíneas com bocas e olhos grandes, como os de uma boneca (Despina KAKOUDAKI, 2004, p. 339). Nas pinups de Willie há diferenças, qual a falta de cores (a revista era impressa em P\&B), expressões faciais quase nunca sorridentes e, claro, um foco no bizarro [fig. 2]. Observa-se um diálogo entre Willie e uma tradição estilística de seu tempo, ora usando-a como base, ora fugindo em busca do incomum. As obras de Willie são unidades coerentemente correlacionadas nas quais se projetam princípios estilísticos capazes de formar unidades maiores em outros planos. A partir desses princípios compartilhados podemos pensar em níveis cada vez mais abstratos aos quais as obras pertencem: o conjunto da obra de J.W., o Estilo de Fetiche Americano ${ }^{11}$, imagens eróticas norte-americanas do séc. $\mathrm{XX}$, e possivelmente outros intermediários, até chegarmos à tradição naturalista ocidental.

Como Alberto Vargas e George Petty, grandes desenhistas de pinups, J.W. buscava verossimilhança em suas ilustrações; como eles, desenhava utilizando modelos vivas ou fotos (cf. XI:64). Segundo Kroll, para Willie, se o desenho parecia real, havia sido um sucesso. Isto nos autoriza a localizar a obra do artista, especialmente suas pinups, na tradição naturalista da arte ocidental (KROLL, 1995, p.8). Em termos gerais, podemos entender tal tradição como buscando a representação icônica, i.e., não arbitrária, guardando semelhanças de forma com o representado. Para tal, artistas apoiam-se em técnicas (como a perspectiva e a aerografia) que aprimoram as semelhanças em direção a um realismo estilisticamente determinado. Estilisticamente determinado porque o realismo não é absoluto, 'reapresentação' de uma realidade ela mesma. Se colocássemos as coisas nestes termos - uma ordem real à qual pertence o representado e uma ordem imitativa à qual pertence o representante -, caminharíamos para uma afirmação como a de Ernest Gombrich: "toda arte é 'feitura de imagens' e toda feitura de imagens se radica na criação de substitutos" (GOMBRICH, 1999, p.9). Poder-se-ia argumentar que o desenho, aqui, seria uma forma de representação mimética que busca reproduzir o natural substituindo-o através da

\footnotetext{
"De acordo com Bienvenu II (1998), O BDSM atual é constituído por três tradições estilísticas distintas: O Fetiche Europeu, o Fetiche Americano, e o Couro Gay.
}

8 Revista Estudos Feministas, Florianópolis, 26(2): e43211 
técnica. Dessa maneira, veríamos uma imagem de uma modelo de salto-alto como mero substituto, imitação, ou cópia empobrecida de uma mulher de salto-alto.

Irônico é que, se pensarmos dessa forma, e se unirmos essa argumentação à teoria freudiana do fetiche, uma foto de uma modelo de salto-alto seria o substituto de um substituto, pois, em Freud, o objeto do fetiche ocupa, no inconsciente do fetichista, o lugar do falo inexistente da mãe. Seu modelo de fetichismo é o do menino que olha para a genitália da mãe e é traumatizado ao perceber que ela é incompleta, que ela não tem a principal fonte de prazer que a criança encontra em seu corpo: o falo. Isso o faz temer a castração, a perda do próprio falo. Desviando o olhar em pânico, o primeiro objeto que o menino encontra em seu campo de visão é colocado inconscientemente como substituto do falo feminino e vira assim fonte de gozo (Sigmund FREUD, 1976). A fórmula resultante é curiosa: o salto-alto ilustrado em Bizarre seria o substituto do salto alto 'real' que por sua vez seria o substituto do falo feminino. E 'substituir' aqui carrega consigo a ideia de empobrecimento, falta, carência: é preciso se contentar com uma foto ou desenho quando não se tem um salto-alto real; similarmente, é preciso se contentar com um salto-alto, posto que mulheres são desprovidas de falos.

Entretanto, se as imagens servissem meramente como substitutas do objeto, se as ilustrações de Willie não passassem de 'reapresentações' imitativas de suas modelos, uma questão ficaria pendente: porque não cortar um dos intermediários e descartar os desenhos em prol das fotos, cópias mais fiéis da realidade por possuírem uma relação indicial e metonímica com o representado? O apreço pelas ilustrações é evidenciado quando Willie pede que seus leitores indiquem suas imagens favoritas e, uma edição depois, as três mais populares são desenhos. Deve haver algo nas ilustrações, para além de sua capacidade mimética, que interessa aos leitores de Bizarre.

Uma carta publicada em XV/XVl:29-34 nos ajuda a pensar no poder das ilustrações. A leitora Dolly conta sobre seu marido, um desenhista de pinups, cujos desenhos eram considerados irrealistas por muitos, pois neles as mulheres teriam cinturas exageradamente finas. Porém, Dolly afirma que ela própria servia de modelo para aquelas ilustrações, e que de fato sua cintura era tão fina quanto as das pinups do marido, já que praticava tightlacing $^{12}$. Porém, se o corpo de Dolly enquadrava-se no molde de uma pinup ideal, seu rosto não o fazia, pois seus olhos e boca, pequenos, não pareciam com os de uma boneca, e por isto seu marido tinha que desenhar os rostos sem modelo, usando a imaginação. Um dia, para surpresa de Dolly, o marido produziu uma máscara de couro branco com uma cara de boneca pintada por cima, e fez a esposa usá-la para posar para ele: possuía uma modelo completa. Acontece que ela gostou de usar a máscara restritiva, que limitava sua visão e respiração, e passou a usá-la também para passar grande parte do dia como uma boneca, sem falar ou expressar emoções.

O relato provoca um curto-circuito nas relações esperadas entre modelo (protótipo), artista, obra (índice) e recipiente (audiência). Uso aqui a nomenclatura desenvolvida por Alfred Gell, oportuna por ter sido cunhada para dar conta do fato de que a fórmula canônica da representação é apenas uma dentre muitas possíveis de se relacionar esses quatro termos (GELL 1998, p. 52ss.). A fórmula da representação é um artista moldando sua obra (índice de sua agência) a partir do protótipo e entregando-a a um público. A princípio é isso que acontece quando Dolly posa para seu marido, com a exceção do rosto, que viria de um padrão preestabelecido estilisticamente (o protótipo de rosto seriam as faces das pinups de Vargas ou Petty que, por sua vez, possuem seus próprios protótipos, suas modelos). A introdução da máscara seria então a ação do segundo protótipo (ele mesmo uma obra,

${ }^{12}$ Treinamento de postura que usa o espartilho cada vez mais apertado para moldar a cintura. 
rosto de pinup) sobre o primeiro protótipo (Dolly), através de um segundo índice (máscara) que o modifica. O ato transforma a modelo por um lado em obra viva - índice da agência do artista - e por outro em protótipo para novas obras-desenhos. Escrevendo à Bizarre, Dolly transforma todo esse evento em um protótipo para um novo índice (carta) que terá como recipientes os leitores.

O incidente atesta a agência dos próprios índices (neste caso, as pinups), capazes não apenas de transformarem-se em protótipos para outras obras, como também de provocarem uma alteração em objetos e pessoas (a máscara e Dolly). O modelo simplista da imitação e substituição é insuficiente quando o representante torna-se representado e distancia-se de um suposto real originário, que passa a ser então não desnecessário, mas insuficiente para a construção da nova obra. Um rosto desenhado pelo marido de Dolly seria substituto da máscara-rosto da esposa, que seria substituto da face da pinup, por sua vez substituto da face da modelo originária? Acredito que não, simplesmente porque a modelo original pouco nos informa sobre o produto final: não é possível cortar intermediários, toda a cadeia é necessária para que a figura final funcione. As ideias de substituição ou cópia tornam-se pouco pertinentes. A 'substituição' ocorre de maneira tão convoluta que deixa de ser mera permuta e passa a ser transformação.

A mesma crítica poderia ser transposta para a teoria freudiana do fetiche: mesmo que o uso de um salto-alto como fonte de desejo sexual tenha ligação com a percepção da inexistência do falo feminino - ponto altamente discutível, como indica, dentre outras, MCCLINTOCK (2003) - tratar o objeto de fetiche como mero substituto é perder de vista sua especificidade enquanto objeto de desejo e prazer. Mesmo que o salto 'substituísse' o falo feminino ao fazer o papel de fonte de gozo, são fundamentais suas especificidades, coisas que o falo não faz: pisa, aumenta a estatura, constrange o pé, impõe curvatura à perna. $O$ fetiche não é subsumível ao falo, assim como uma obra não é subsumível ao protótipo, mesmo que, realista, possua relações indiciais com este. Ao invés de ideias como imitação, cópia, substituição, parecem mais ricas as de influência ou afecção, mesmo que, em muitos casos, as afecções envolvam repetição ou projeção de características formais de um protótipo em um índice. Há certamente casos onde o protótipo é a base da construção da aparência de uma obra, em que são essenciais critérios rígidos de realismo e naturalismo. Porém, entre protótipo e índice há sempre transformações fundamentais, que geram diferenças capazes de tornar o segundo sui generis em relação ao primeiro. Se há "imitação" aqui, ela não se limita à cópia e substituição: trata-se de imitação criativa, diferencial.

\section{Imaginação}

Livre da ideia de substituição, sigo Thomas Freedberg quando afirma que nossas respostas a imagens podem ser da mesma ordem de nossas respostas à realidade, e que por isso devemos fazer tombar sobre si mesmas distinções rígidas entre as ordens natural e imitativa (FREEDBERG, 1989, p. 438). Assim, podemos pensar nas potencialidades das imagens de Willie, no que fazem e como, não no que substituem. No editorial de IX, o artista afirma que, pelo grande número de sugestões de leitores, a edição tem mais desenhos e menos fotos. Não é impossível fotografar sugestões dos leitores, mas o desenho é mais apto a transformá-las em imagens. Em muitas descrições por carta, o protótipo não é algo concreto, mas imaginado, e uma ilustração é mais descolada da matéria que a foto, não possui relação física indicial com seu referente. O desenho abre caminho mais facilmente ao imaginário. Entendo imaginário, seguindo Vincent Crapanzano, como um espaço-tempo optativo que abre horizontes de possibilidades através de sua irrealidade, imprimindo novas formas à realidade. "A consciência imaginativa nos permite transcender a imediatez 
do instante presente a fim de apreender um futuro que é a princípio indistinto [...], mas permite projetar nossas 'fábulas' em uma direção que não necessita enfrentar o 'universo evidente'" (CRAPANZANO, 2004, p. 19).

Notamos, ao longo da revista, o efeito das imagens na imaginação dos leitores: S.W. diz querer ser dominado por uma mulher como a ilustrada em Ill:16 [fig. 2] - "Penso que seria eletrizante e excitante ser o disciplinado escravo de uma criatura tão fascinante" (V:12). Outros exemplos mostram que também fotos são capazes de excitar a imaginação. Ibitoe argumenta: "Sei que muita gente acha ridículo fotografar sapatos sem pés dentro, mas acho que fotos de sapatos vazios podem ser excitantes para se contemplar a aparência e forma do pé que DEVE ENCAIXAR NO SAPATO" (XXIII:39, ênfase no original). Outro leitor pede mais textos sobre os espartilhos descritos por Paula Sanchez e pede que J.W. os ilustre, pois:

Frequentemente sonhamos com nossa dama ideal. Ela seria um verdadeiro pesopesado, com tremendo contraste entre o amplo busto intumescido, a pequena cintura, e as proeminentes 'curvas traseiras', pequenos pés tamanho 17 cambaleando em elevados saltos-agulha, rosto muito maquiado, cachos loiros claros, quilos de joias por todos os lados, longas unhas vermelhas e um vestido ameaçando arrebentar pela pressão a qualquer minuto. Ela seria uma verdadeira boneca artificial e indefesa, capaz de andar apenas em pequenos passos cambaleantes (XIV:54).

Percebemos uma produção de imagens mentais minuciosas, a partir de fotos, desenhos, descrições, experiências anteriores e outras fontes. Cada suporte tem sua relação específica com o concreto e possui suas características próprias; a descrição é narrativa, possui uma sequência, enquanto fotos e ilustrações apresentam o objeto de uma só vez possivelmente a imagem mental criada por uma descrição é mais fugidia e abstrata que a originada de um desenho. Há ainda imagens narrativas, como as histórias em quadrinhos. Outras distinções poderiam ser traçadas, mas o que interessa é perceber a importância da imaginação no processo engatilhado por Bizarre em seus leitores. A imaginação é um modo particular da excitação, mas deve ser sublinhada devido ao seu caráter antecipativo e sua capacidade de transpor as barreiras do real imediato, gerando um plano virtual.

Neste sentido, as imagens mentais em jogo aproximam-se do que Colin Campbell chama de 'hedonismo autoilusivo'. O autor aponta para a possibilidade de um prazer derivado de construções imaginativas como a fantasia e o devaneio, um prazer que se dá através da antecipação do acontecimento, instigando o agente a manipular imagens advindas da memória de modo consciente e eficaz.

A introdução do devaneio no hedonismo, portanto, não só reforça o desejo como ajuda a fazer o próprio desejar uma atividade agradável. Enquanto para o homem tradicional a satisfação adiada significaria simplesmente a experiência da frustração, para o homem moderno ela se torna um hiato feliz entre o desejo e a consumação que pode ser satisfeita com as alegrias do devanear. Isso revela um aspecto único do moderno hedonismo autoilusivo - o fato de que o modo de desejar constitui um estado de desfrutável desconforto, e de que precisar mais do que ter é o foco principal da procura do prazer (Colin CAMPBELL, 2001, p. 126).

O autor descreve uma forma de prazer e excitação interiorizada, que age na tensão entre perfeição e possibilidade, na interação dinâmica entre real e imaginado. Apenas entendo que, ao invés de chamá-lo de 'autoilusivo', seria melhor chamar tal hedonismo de 'imaginário'. Assim como 'substitutos' podem ser mais efetivos que 'originais', o imaginário pode ser tão ou mais prazeroso que o concreto. Sobretudo quando a imagem mental aponta para o impossível, ou melhor, quando a construção mental é fantasia, e não devaneio. 
Conforme descrito na fortuna crítica em torno da obra de Sade, o impossível é constitutivo de toda a excitação sádica (Roland BARTHES, 1979; Eliane Robert de MORAES, 1994.) Quando se preza, como em Bizarre, pela consensualidade, o impossível ganha ainda mais destaque. Pois, se o submisso consente em colocar-se em inferioridade ou sofrimento de bom grado, não está de fato sendo dominado. O paradoxo da 'dominação consensual' é tema constante do BDSM, sendo a fantasia uma das maneiras de superá-lo: se o submisso não é real, não precisa consentir com nada, a dominação é 'pura'. ${ }^{13}$ Há imagens impossíveis na revista: na capa de XXIII, uma domadora amansa seus homenscachorro; há referências a ilhas longínquas onde habitam mulheres de 13 pés de altura em saltos de 13" (XIII:5). Figuras inverossímeis, mas sempre colocando o impossível em tensão com o possível. Assim podemos entender as discussões intermináveis ao longo da revista sobre a possibilidade ou impossibilidade do salto de 6" e do espartilho de 11 " (IV:20, V:1 1, X:40, XIV:47). Se há um desenho fantástico de um tight-lacing tão radical que faz a cintura quebrar ao meio (IV:17), há também sérios desenhos e cálculos geométricos para provar a possibilidade do salto de 6" (XII:51).

Os exemplos mostram o pendor da imaginação a buscar extremos, ideais, borrando as fronteiras do irrealizável. Isso não se dá na pura abstração, pois o mundo material, atual, não é ignorado, faz-se presente como limite e referência à construção imaginativa. Neste sentido, a necessidade de realismo se coloca no hiato entre a 'vida real' e o imaginário (CRAPANZANO, 2004, p. 128). O naturalismo, além de outras funções, é capaz de afetar a imaginação de uma maneira singular, projetando nela características vivas do protótipo. Para serem capazes de gerar imagens mentais satisfatórias no registro que estudamos, as imagens devem ser relativamente realistas e as descrições, detalhadas. Creio ser isso que a carta em XXIII:50 afirma, ao elogiar uma foto, dizendo: "para mim, tal figura tem um impacto maior ainda porque é tão realista [true to life]". Em se tratando de descrições escritas, é a minuciosidade que provoca o gatilho naturalista. Em VII:47-50 aparece uma descrição ultradetalhista de uma roupa de cowgirl, estendendo-se por quatro páginas, detendo-se em quão apertada deve ser, como deve ser polida, onde brilha etc. Em XXII:24, High Heel Artiste assevera: "quanto mais forem pessoais e detalhados os artigos, mais serão apreciados pelos leitores".

Outra forma que a imaginação encontra para lidar com o paradoxo da dominação consensual é buscando futuros ou passados idealizados ou fantasiosos. Para futuras décadas, os leitores imaginam modas mais bizarras - saias mais apertadas, couro mais brilhante (III:30; III:43; VII:55), e civilizações utópicas governadas por mulheres dominadoras, que escravizam os homens (IX:32). Para o passado, deliciam-se com imagens de um suposto tempo - antiguidade egípcia e grega, idade média, era vitoriana - quando a exigência de disciplina era maior, quando as torturas públicas eram comuns, quando as roupas eram mais constrangedoras, quando existia escravidão. De forma similar, argumentam contra "métodos educacionais modernos" e a favor da volta da disciplina rígida e da punição corporal que sofreram na infância, provocando-lhes seu desejo masoquista atual. Num movimento irônico, uma estranha espécie de conservadorismo é colocada a serviço da sexualidade dita 'desviante', algo que também ocorre na obra de Sade (BEAUVOIR, 1955; MORAES, 1994).

Porém, há uma dissonância com relação ao monstro sadeano: aqui o desejo não é somente de imaginar um outro tempo no qual o fetichista seria um dominador; eles afirmam

\footnotetext{
${ }^{13}$ Outro modo de lidar com o paradoxo é através da teatralidade. McClintock (2003, p. 24) apresenta uma interessante análise do sadomasoquismo como teatro da conversão, dos signos e dos riscos, que reverte e transforma os significados sociais.
} 
querer a volta de algo que, prazerosamente, os oprima. Tais referências idealizadas a passados e futuros indicam uma rejeição ao tempo atual, às normas do presente. Os leitores de Bizarre veem seus gostos não convencionais como provas de sua extemporaneidade. Willie expõe com clareza: "Bizarre - a revista para o agradável otimista que desaprova a convenção. A revista de modas e gostos fantásticos! Inumeráveis periódicos lidam com ideais para a maioria, para que todos sigam seus rastros como ovelhas!" Para o editor, Bizarre e seus leitores não são conservadores, old-fashioned ou futuristas, possuem apenas "o gosto e a habilidade de criar o incomum e heterodoxo à tendência do momento" (III:2).

\section{Identificação e Multiplicação}

Observando-se extemporâneos, estranhos ao tempo e mundo em que vivem, os leitores de Bizarre alegram-se em perceber que não estão sozinhos em suas preferências heterodoxas. Alguns o expressam claramente: Mrs. XYZ afirma que ela e seu marido precisam da revista porque "não somos um casal comum, e frequentemente nos sentimos sozinhos no mundo" (XIl:29). Sylvia Soulier afirma: "as ilustrações de meus próprios sapatos podem ajudar outros a entenderem que não estão sozinhos em suas preferências" ( $X: 17)$. A revista promovia um movimento de identificação; ao folhearem-na, as pessoas notavam haver outros com desejos, interesses, gostos e paixões similares. Chamo de identificação o agenciamento que, a partir da comparação das imagens e textos de Bizarre com fantasias, memórias e preferenciais pessoais, leva à percepção de que os lados comparados vibram na mesma frequência, excitam-se com o mesmo tipo de coisa. Nas palavras de Bettie $C$., "Bizarre preenche uma necessidade e oferece um meio de troca de ideias para aqueles forçados pelas circunstâncias a comprazer-se com o não convencional" (XI:52). Fugindo da convenção, auxiliados pela mediação de Bizarre, as pessoas podiam sentir-se parte de um conjunto, o seleto mundo do fetiche. A revista não era a única força centrípeta a atrair interessados em tal estética, mas certamente foi um nó na criação de uma rede de praticantes e aficionados por estes temas, que viriam se chamar BDSM.

Entretanto, a percepção de semelhanças não instaura homomorfismo na rede, especialmente pelo fato de que a similitude identificada diz respeito ao desvio, ao incomum, à diferença. As pessoas percebem aproximações de gosto e de preferência, e passam a se ver como pares, mas não necessariamente como iguais. Basta olhar para as polêmicas nas seções de cartas de Bizarre. A tatuagem, tema pouco frequente na revista, foi capaz de, em apenas três páginas, provocar a ira de L.E.S., que se disse estarrecido com as ditas páginas, pois a tatuagem não seria bizarra, mas visual e esteticamente grotesca, por camuflar as curvas do corpo, glorificando apenas a força selvagem contra a verdadeira forma (XIX:19). Harold Ford defende a tatuagem, diz que o fascinante nela é ser "invulgar e ousada" (VIII:30). Em uma controvérsia surpreendentemente específica, três leitores atacam o editor, tratando do uso de botas: devem ou não ser apertadas ao ponto de a carne da perna formar protuberâncias sobre o cano? Para argumentar, usam fotos - talvez similares para um leigo - como exemplos de perfeição ou terror, dependendo do gosto (VII:32-37). Com ironia, Willie apresenta duas páginas depois um par de fotos da mesma modelo na mesma posição, ora com salto alto e coxas de fora, ora com botas que vão até a virilha [fig. 3].

Os debates atestam que, apesar de os leitores de Bizarre identificarem-se na extemporaneidade e extravagância uns dos outros, isso não dissolve suas diferenças, levando-os a uma identidade inequívoca: as discordâncias acentuam-se em alguns pontos e abrandam-se em outros. Regina Facchini e Sarah Machado (2013, p. 222) notam, analisando uma polêmica no BDSM contemporâneo brasileiro, a dificuldade de valer-se do conceito de 'identidade' como usado no contexto LGBT. Mesmo que sejam 'adeptas' de 
um estilo de vida BDSM, o caráter teatralizado, múltiplo e bizarro desta estética impede que suas diferenças sejam levadas a um suposto grau zero. ${ }^{14}$ Cada leitor tem suas preferências, paixões, fetiches. Uns defendem espartilhos, outros só se interessam por salto altos; alguns dizem-se amantes da borracha, outros preferem o couro ou a renda. Contra a padronização, J.L.C. argumenta: "devemos ser todos zumbis estandardizados [...]? O que precisamos é de individualidade mais enfatizada" $(\mathrm{V}: 7) .15$

Está em jogo aqui a formação dinâmica de gostos. Entendo o conceito de 'gosto', a partir de Antoine Hennion, como uma modalidade reflexiva de ligação com o mundo, na qual objetos, coletivos e corpos agem uns sobre os outros. "Gostar não é assinar sua identidade social [...] É uma performance: isto age, isto liga, isto transforma, isto faz sentir [...] Reciprocamente, a produção de um gosto 'faz' suas propriedades coletivas, pouco a pouco definidas e estabilizadas por aquela comunidade" (HENNION, 2005, p. 5-6). Preferências pessoais e idiossincrasias permanecem relevantes, formando o coletivo no mesmo passo em que se formam com ele.

Repito: a identificação não leva à criação de uma 'identidade', no sentido de autopercepção de pertencimento a um grupo marcado pelo homomorfismo de seus membros. Pelo contrário, o que percebemos, lendo Bizarre cronologicamente, é uma crescente multiplicação de gostos e possibilidades eróticas. A princípio bondage, couro, disciplina, salto-alto e espartilho dominam as páginas, mas aos poucos tais temas vão dando espaço a novos, quase sempre por sugestão de leitores. Vão surgindo cabelos longos, pessoas aleijadas, peças de borracha, cigarros, piercings etc. Enquanto os fetiches e paixões proliferam, Willie afirma que o editor deve ser imparcial e publicar tudo que foge do escopo de outras publicações, tudo que for bizarro. O quanto o editor de fato controla o conteúdo da seção de correspondência é difícil precisar.

O adjetivo 'bizarro', além de dar nome à revista, aparece na publicação - e, em menor grau, no BDSM contemporâneo - como forma de marcar a estranheza da sexualidade, porém sem sentido pejorativo. Há de se lembrar de que, à época de Bizarre, a ideia de 'pornografia bizarra' e os clichês midiáticos do sadomasoquismo, que hoje conhecemos, sequer existiam. ${ }^{16} \mathrm{O}$ bizarro que aparece ali é de certa maneira excêntrico, talvez possua um toque de grotesco que pode ser chocante para muitos, porém não é anormal no sentido de patológico. Uma estética 'bizarra' vai se delineando ao longo da revista, marcada pela multiplicidade sexual, restringida apenas pela fuga do convencional, do mainstream. Em muitos sentidos, o 'bizarro' que aparece na revista faz lembrar definições (sempre necessariamente abertas) da noção, hoje corrente nas humanidades, de queer, enquanto uma posição que "dramatiza incoerências nas supostamente estáveis relações entre sexo cromossomial, gênero e desejo sexual [e] resiste ao modelo da estabilidade" (Annamarie JAGOSE, 1996, p. 3). Como o queer, o bizarro e o BDSM podem ser nódoas nas teorias (e políticas) mais homogeneizantes da identidade (JAGOSE, 1996, p. 131). ${ }^{17}$

\footnotetext{
${ }^{14}$ Algo que, como argumenta Butler (1990), em consonância com teorias anti-fundacionistas, só existe como silogismo político criado como efeito ilusivo da repetição e normatividade de práticas discursivas e performances. ${ }^{15} \mathrm{Há}$ algo nesse tipo de afirmação que revela o local e tempo de Willie, pendendo entre um discurso liberal individualista (tão característicos da classe média nos EUA pós-guerra) e o ainda em germe discurso da libertação sexual. Porém, seu caráter extemporâneo ressoa também, como vimos, através de visões conservadoras e elitistas da estética e da educação (possivelmente herdadas do vitoriano fetiche europeu). ${ }^{16}$ Sobre a pornografia bizarra, ver LEITE Jr., (2009).

${ }^{17}$ Devo sublinhar que aproximações entre o queer e o BDSM parecem fecundas - e já foram ensaiadas por autores como WEISS (2006) e Darren LANGDRIDGE; Trevor BUTT(2004) mas devem ser feitas com cuidado. No caso de Bizarre, ao menos, um dos aspectos fundamentais do queer - a desnaturalização - não está presente.
}

14 Revista Estudos Feministas, Florianópolis, 26(2): e43211 
A multiplicação de desejos e prazeres parece ser um dos movimentos mais importantes provocados por Bizarre, pois não apenas a revista torna-se mais variada: a multiplicação provoca novas formas e empresta novos gostos aos leitores; cada um, aos poucos, aprende novas possibilidades de excitação, novas técnicas, novos interesses. Uma pessoa que gostava apenas de amarração aos poucos pode se fascinar por salto-alto, borracha, chicotes... E assim a ideia freudiana da cena inaugural, fálica, do fetiche, perde ainda mais sua potência explicativa.

As variações são muitas, a multiplicação que emergira das sugestões dos leitores vai atingindo outros, através da rede de excitação criada. Vemos Slightly Chastened passar pelo susto e pelo choque, pelo orgulho ultrajado e pela indignação até chegar à fascinação e à curiosidade sobre a posição de Lady Master na carta "Abaixo às escravas", onde defende a dominação dos homens pelas mulheres. Por fim, pede mais detalhes. Excitou-se. M.F. simplifica: "meu desejo ao ler Bizarre é simplesmente viver uma mentalidade e uma atmosfera bizarra". Ele procura "modos de fazer do bizarrismo uma fonte quase inesgotável de gozo e satisfação sexual", e afirma: "estou aprendendo muitos novos e interessantes métodos e truques do ofício" (XXIl:20).

Uma das formas de multiplicação que encontramos ao longo de Bizarre diz respeito às relações de gênero. A revista, que à primeira vista parece direcionada para homens heterossexuais dominadores, aos poucos vai incluindo mais e mais imagens de mulheres fora da posição de submissão. Leitoras e colaboradoras mulheres passam a ser mais frequentes e imagens de homens timidamente vão surgindo ao longo dos números - boa parte praticando o cross-dressing [fig. 4]. E toda uma polêmica se desenvolve acerca da perda ou não da masculinidade de um homem em vestimentas femininas (por exemplo, XV/ XVI:70-71). Verdade, a esmagadora maioria das imagens de Bizarre continua sendo de mulheres e a homossexualidade é raramente referida, apesar de muitas vezes implícita. Sem dúvida há uma tendência heterossexualista, branca, burguesa e masculinista que dá o tom da revista, desde seu primeiro número, evidenciada, por exemplo, quando Willie inicia um artigo falando, com humor, sobre como retomar a supremacia masculina nas relações e calar as mulheres. Ele apresenta desenhos de mordaças com instruções de uso: todas as ilustrações são de mulheres amordaçadas, mas no final do texto J.W. diz que os aparelhos servem também para homens (X:8). Talvez o editor - homem, heterossexual e dominador - direcione a revista no sentido de suas preferências, mas os leitores, em suas cartas, abrem linhas de fuga em direção à dominação feminina, à homossexualidade, à androgenia e à travestilidade, que John Willie acata sem muita resistência. ${ }^{18}$

Se em Bizarre vemos uma multiplicação das relações de gênero que provocam o início de uma explosão no sexismo da revista, restam pontos não expostos a tal tipo de movimento, em nada contra-hegemônicos. A questão racial, por exemplo, jamais se expressa como relevante para o editor ou para os leitores, e a única imagem de corpo negro que aparece na revista é um desenho de uma criada em espartilhos, servindo um homem branco (XIX:15) [fig. 5]. A figura - de uma vez típica dos EUA sob as leis Jim Crow e nostálgica pela rigidez vitoriana - ilustra a coluna de Paula Sanchez, memórias da relação de sua família com espartilhos. Neste episódio, duas criadas "de cor" são forçadas pela avó de Sanchez a

${ }^{18}$ Fads and Fancies, revista fetichista britânica contemporânea a Bizarre, era editada por uma mulher, Reina Bull. Uma comparação seria valiosa e talvez nos ajudasse a compreender porque o editor homem, Willie, ganhou mais destaque na história canônica do BDSM do que Bull. De forma similar, seria rico comparar Willie com outros produtores consagrados de erotismo BDSM, nos quais as tendências heterossexualistas ou masculinistas são menos fortes - como Eric Stanton (cujo foco sempre foi em mulheres dominadoras e homens submissos) e Tom of Finland, possivelmente o maior expoente das artes visuais do chamado couro gay - cf. Eric STANTON (2001); Ramakas MICHA (1992). 
praticar o tight-lacing e, ainda que na narrativa as criadas sintam-se orgulhosas da silhueta resultante, é difícil encontrar qualquer vestígio de negociação e contestação das contradições de classe e raça através do fetichismo - quais as observadas por McClintock na análise dos diários e fotos de um casal vitoriano. Não discordo da autora quando esta afirma que $\circ$ sadomasoquismo "faz o poder social andar para trás, encenando visível e ultrajantemente a hierarquia, a diferença e o poder, o irracional, o êxtase ou a alienação do corpo [...]" (MCCLINTOCK 2003, p. 25). Apenas há de se compreender que, se a encenação tem potencial subversivo, este nem sempre é atualizado. ${ }^{19} \mathrm{Se}$, por vezes, o BDSM apresenta o jogo do prazer como espaço de possibilidade utópica, como coloca bell hooks, isso nem sempre acontece; "no espaço de trabalho real [...] compostura de classe, hierarquia racial e heterossexismo prevalecem". (hooks, 1996, p. 93). ${ }^{20}$ As virtualidades transgressoras criadas nos cenários teatrais BDSM nem sempre são transportados com sucesso para além do espaço íntimo e, de fato, nem sempre os adeptos estão interessados em fazê-lo.

\section{Conclusão}

A interrupção da multiplicação em Bizarre nos convida a interromper o texto. Sem dar sequência ao importante debate sobre em que medida práticas sexuais 'heterodoxas' podem ser consideradas contra-hegemônicas em seus efeitos sociais, limito-me a propor que objetos e imagens relacionadas a tal heterodoxia possuem potencialidades subversivas para o pensamento. Quer aceitemos o sadomasoquismo e o fetichismo como subversivos ou não, tais práticas - que já foram descritas como 'perversões' - talvez possam ser descritas como hiperbólicas. Acentuam, paroxisticamente, traços ubíquos da sexualidade do contexto no qual emergem. O sadomasoquismo parece ser um caso privilegiado para pensar questões de violência e poder inerentes a qualquer forma de relação sexual - como atesta o debate esboçado acima.

Mas o poder, apesar de essencial, não é a única questão relevante. Diferente do sadomasoquismo, o fetichismo sexual - desde que o termo foi cunhado por Alfred Binet parece ser um caso privilegiado para pensar no caráter imaginativo da fantasia sexual (Binet dizia "ruminações eróticas") e, principalmente, a questão da idiopatia, isto é, a preferência aparentemente imotivada de cada pessoa por certos objetos, partes do corpo, materiais, formas, cores, cheiros etc., enfim o gosto, as predileções na esfera sexual (BINET, 1887). É interessante que Binet tenha escolhido transpor das descrições de viajantes e filósofos da África Ocidental o termo 'fetichismo' para nomear tais práticas. O parentesco entre os objetos de poder que espantaram os europeus na Costa do Ouro e os objetos de

\footnotetext{
${ }^{19}$ Analisando um contexto bastante distinto, no qual o "contrato do realismo" é mais essencial do que aquele em Bizarre, e no qual a questão do consenso é bastante mais ambígua - a produção de pornografia de humilhação - Díaz-Benítez faz aparecer uma semelhança interessante com os tensores libidinais da carta de Paula Sanchez. Ela afirma que "em meio a enredos que evocam hierarquias sociais, como a relação patroa/ empregada, que é, de fato, o mais comum nessas performances" (DÍAS-BENíTEZ, 2015, p.66).

${ }^{20}$ Ainda que seja acusada por feministas radicais de ser uma defensora do sadomasoquismo - e, portanto, do patriarcado (cf. DWORKIN 1997), há de se notar que a posição de bell hooks sobre o assunto é bastante complexa. É frequente, em sua obra, o uso do termo sadomasoquismo como sinédoque para a relação conjugal heteronormativa que opõe opressores e oprimidos. Ver também sua crítica ao sadomasoquismo como o defendido por Madonna (hooks, 1994) e sua apreciação do potencial do BDSM lésbico para a discussão feminista (hooks, 2000, p. 85-99). Ainda no tema da raça, cabe indicar as contribuições das feministas negras Alice Walker, Karen Sims, Rose Mason e Darlene Pagano ao clássico do feminismo radical Against Sadomasochism (Robin Ruth LINDEN et al, 1982, p. 99-105; 205-8). Tais autoras problematizam a ideia de que a comunidade BDSM seria uma minoria oprimida, defendendo que experimentar com relações de poder é um luxo reservado às classes altas e brancas. Elas também atacam o uso da imagem da escrava, ou mesmo da criada, no jogo sexual.
} 
excitação 'monomaníaca' sexual de certos 'pervertidos' estaria na confusão entre a divindade e o signo que a representa, isto é, na fusão entre significante e significado, material e imaterial (cf. Rogério Brittes W. PIRES, 2014). Binet cria um paralelo entre a projeção de superstições sobre estátuas de pau e pedra e a projeção de desejos eróticos sobre objetos não sexuais. A ideia é que fetiches - sexuais e religiosos - são objetos que concentram poder. Descartemos as ideias de confusão, de doença, de ilusão, de projeção. Para além de uma ideia de um desejo íntimo, edipiano e idiossincrático, os efeitos analisados, de identificação e multiplicação, demonstram o contínuo entre externo e interno, objeto e sujeito, real e imaginário. Um fetiche pode levar a novos fetiches, um fetichista pode ativar o fetichismo em outras pessoas.

As imagens contidas em Bizarre são, nesse sentido, fetiches (ou, pace Latour, fatiches), simultaneamente fatos e feitos, dados e construídos, carregados com um poder que não está necessariamente nem neles próprios, nem na mente ingênua de quem os observa, e sim nas relações que travam, nas associações que possibilitam, em suas afecções e influências. São agentes indispensáveis na rede que compõem, não apenas coadjuvantes de desejos humanos. Não são nem origem da força por detrás dos acontecimentos sociais que os cercam, nem mera matéria dessubjetivada em torno da qual agem sujeitos livres.

A ideia da excitação é boa para tomar como conceito, a fim de pensar a agência na pornografia e erotismo em geral, pois significa tanto a provocação de desejos e práticas eróticas quanto a estimulação que incita à ação. Bizarre excitava seus leitores ao mesmo tempo em que era excitada por eles, levando a uma multiplicação de possibilidades sexuais atuais e virtuais. Não há aqui origem privilegiada da ação em nenhum dos termos em interação, humano ou não humano, real ou imaginária. A força da excitação vem da própria relação. A excitação é distribuída ao longo de toda a rede; cada movimento, de mão dupla, tripla, ou múltipla, provoca novas agitações. As cadeias de excitação atravessam modelos, artistas, publicações, públicos, passados, futuros, imaginações do possível e do impossível, construindo imagens mentais, ilustrações, fotos e textos, atualizando possibilidades e desejos eróticos dos mais diversos. A cadeia gera um movimento de identificação e de conexão, no sentido de reconhecimento de semelhanças, de certo ajustamento delas e de estabelecimento de relações sociais. Mas a identificação não se encerra em uma identidade, seja ela pessoal, de gênero ou 'subcultural', pois o movimento é superado pelo de multiplicação, que aponta para uma diversidade de fetiches, de imagens, de erotismos e de estéticas, vistas, pela sua multiplicidade mesmo, como bizarras. 


\section{Imagens}

Figura 1: Bizarre 5, p. 30; 7, p. 39 e 11, p. 66. A transformação de uma imagem retirada de uma revista de 1880 , enviada por um leitor, em desenho de J.W. e em foto de leitora. Domínio público.

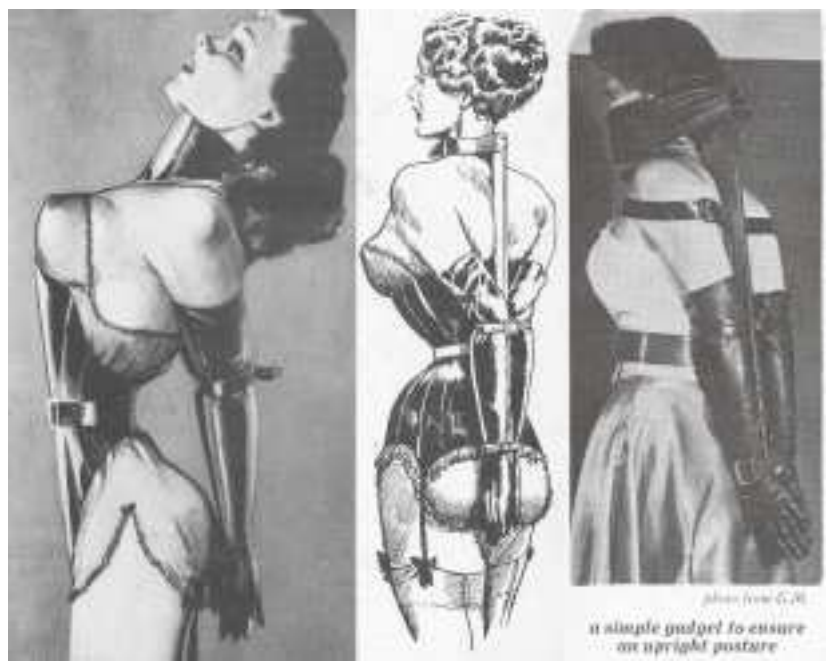

Figura 3: Bizarre 7, p. 32 e 18, p. 29. Uma polêmica sobre botas. Domínio público.

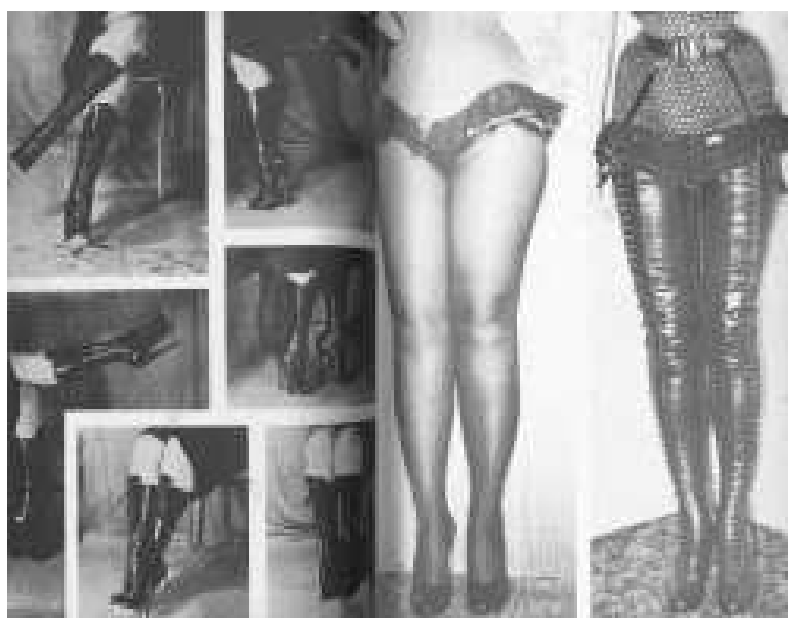

Figura 2: Bizarre 3, p. 16 Exemplo de pinup de J.W. Domínio público.

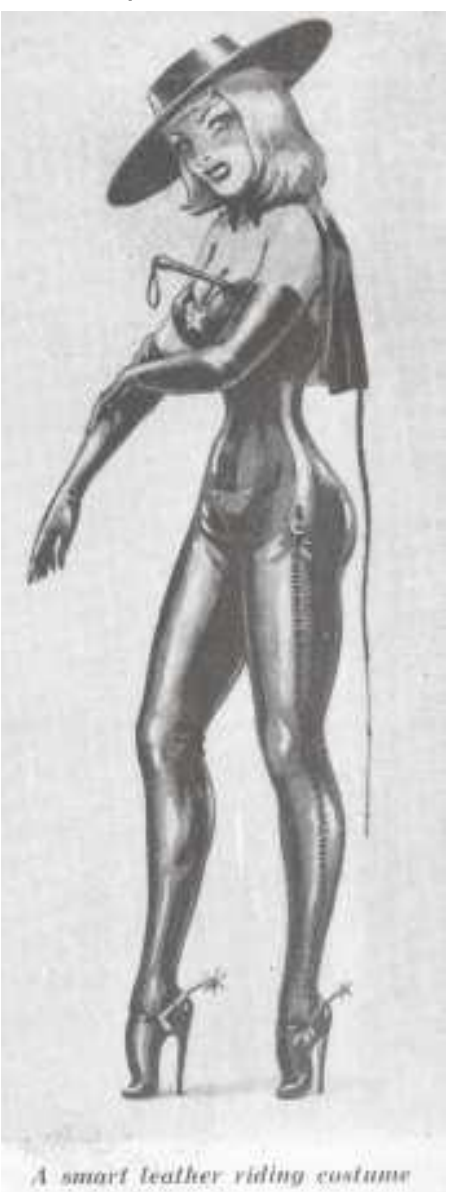

18 Revista Estudos Feministas, Florianópolis, 26(2): e43211 
Figura 4: Bizarre 12, p. 19. Homens em Bizarre. Domínio público.

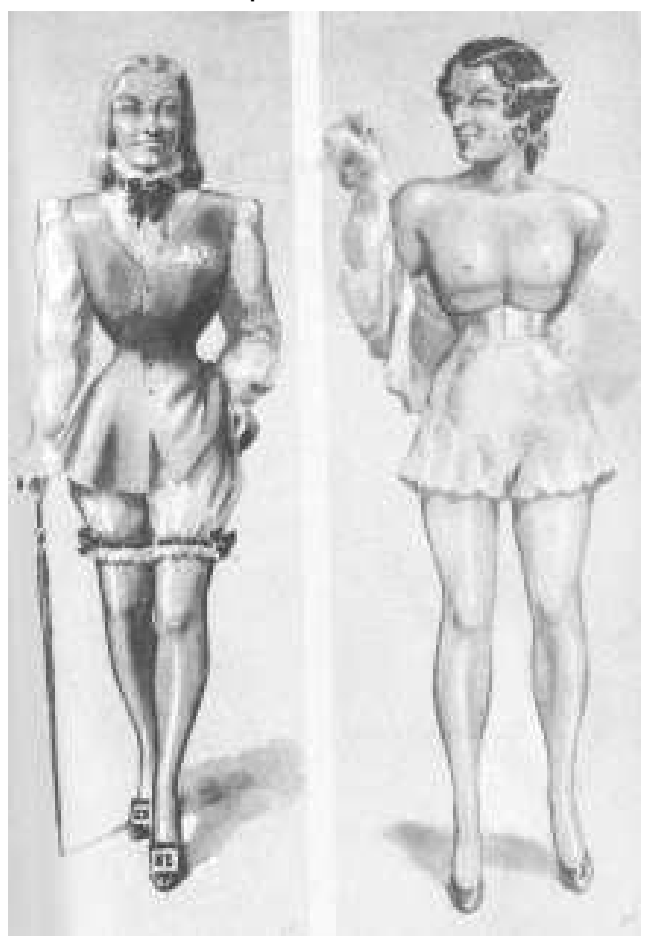

Figura 5: Bizarre 19, p. 15. A criada negra nas memórias de Soulier. Domínio público.

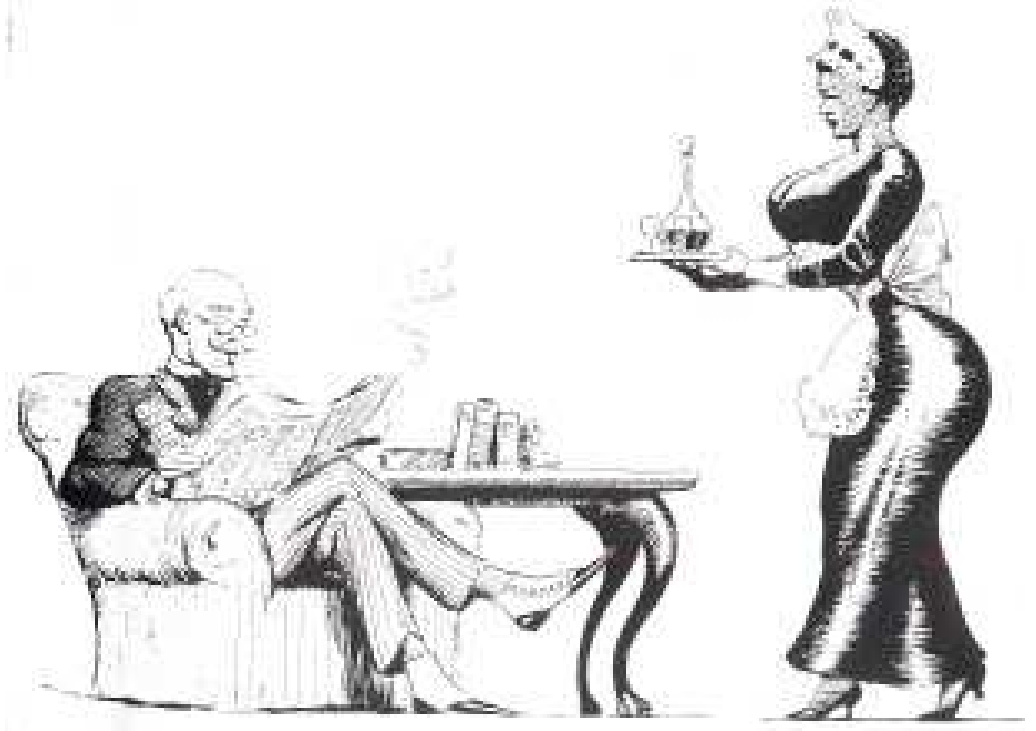

Revista Estudos Feministas, Florianópolis, 26(2): e43211 19 


\section{Referências Bibliográficas}

BARTHES, Roland. Sade, Fourier, Loyola. London: Jonathan Cape, 1979.

BEAUVOIR, Simone de. Faut-il brûler Sade?. Paris: Gallimard, 1955.

BIENVENU II, Robert. The development of sadomasochism as a cultural style in the twentiethcentury United States. 1998. Dissertation (PhD, Sociology). Indiana University, Bloomington, IN, USA.

BINET, Alfred. "Le fétichisme dans l'amour". Revue de Philosophique de la France et de l'Étranger, Paris, n. 24. p. 143-167. 1887.

BUTLER, Judith. Gender trouble: feminism and the subversion of identity. New York: Routledge, 1990.

"Against ethical violence". In: BUTLER, Judith. Giving an account of oneself. New York: Fordham University Press, 2005. p. 41-83.

CALIFIA, Pat. "Feminism and Sadomasochism". In: CALIFIA, Pat. Public sex: the culture of radical sex, $2^{\text {nd }}$ Edition. Jersey City: Cleis Press, 2000. p. 168-180.

CAMPBELL, Colin. A ética romântica e o espírito do consumismo moderno. Rio de Janeiro: Rocco, 2001.

CRAPANZANO, Vincent. Imaginative horizons: an essay in literary-philosophical anthropology. Chicago: University of Chicago Press, 2004.

DÍAZ-BENÍTEZ, María Elvira. Nas redes do sexo: os bastidores do pornô brasileiro. Rio de Janeiro: Zahar, 2010.

"O espetáculo da humilhação: fissuras e limites da sexualidade". Mana, Rio de Janeiro, v. 21, n. 1, p. 65-90, abril, 2015.

DWORKIN, Andrea. "Mr. Bataille's Little Girl", Times Higher Education. London, 1997. Disponível em http://www.timeshighereducation.com/books/mr-batailles-little-girl/160039.article Acesso em 29/03/2018.

FACCHINI, Regina; MACHADO, Sarah. "'Praticamos SM, repudiamos agressão': classificações, redes e organização comunitária em torno do BDSM no contexto brasileiro". Sexualidad, Salud y Sociedad, Rio de Janeiro, n. 14, p. 195-228, ago., 2013.

FOUCAULT, Michel. História da sexualidade 1 - A vontade de saber. Rio de Janeiro: Graal, 1988.

FOUCAULT, Michel; O'HIGGINS, James. "Sexual choice, sexual act: an interview with Michel Foucault”. Salmagundi, Saratoga Springs, v. 58, n. 9, p. 10-24, inverno, 1983.

FREEDBERG, Thomas. The power of images: studies in the history of response. Chicago: University of Chicago Press, 1989.

FREUD, Sigmund. "Fetichismo". In: Obras completas ESB, vol. XXI. Rio de Janeiro: Imago, 1976.

GELL, Alfred. Art and agency: an anthropological theory. Oxford: Claredon, 1998.

GOMBRICH, Ernst. "Meditações sobre um cavalinho de pau ou as raízes da forma artística". In: GOMBRICH, Ernst. Meditações sobre um cavalinho de pau e outros ensaios sobre a teoria da arte. São Paulo: EdUSP, 1999. p. 1-11.

GREGORI, Maria Filomena. "Prazer e perigo: notas sobre feminismo, sex-shops e S/M". In: PISCITELLI, Adriana; GREGORI, Maria Filomena; CARRARA, Sérgio (orgs.). Sexualidade e saberes: convenções e fronteiras. Rio de Janeiro: Garamond, 2004. p. 235-256.

GUILMETTE, Lauren. "Reading Butler, reading Beauvoir, reading Sade". Philosophy Today, Chicago, n. 55, p. 292-301, out., 2011.

HENNION, Antoine. "Pour une pragmatique du goût". Papiers de recherche du CSI, Paris, n. 1, p. 1-14, 2005. 
hooks, bell. "Power to the pussy: we don't wannabe dicks in drag". In: hooks, bell. Outlaw culture: resisting representations. New York: Routledge, 1994. p. 9-26.

. "Thinking through class: paying attention to The Attendant". In: hooks, bell. Reel to real: race, sex and class at the movies. New York: Routledge, 1996. p. 91-97. . Feminism is for everybody: passionate politics. Cambridge: South End, 2000.

JAGOSE, Annamarie. Queer theory: an introduction. New York: Melbourne University Press, 1996.

KAKOUDAKI, Despina. "Pinup: the american secret weapon in World War II". In: WILLIAMS, Linda (ed.). Porn Studies. Durham: Duke University Press, 2004. p. 335-369.

KROLL, Eric. "John Willie is Bizarre". In: WILLIE, John. The complete reprint of John Willie's Bizarre. Köln: Taschen, 1995. p. 6-17.

LANGDRIDGE, Darren; BUTT, Trevor. "A hermeneutic phenomenological investigation of the construction of sadomasochistic identities". Sexualities, Colchester, v. 7, n. 1, p. 31-53, fev., 2004.

LATOUR, Bruno. Reflexão sobre o culto moderno dos deuses fe(i)tiches. Bauru: Edusc, 2002.

LEITE Jr., Jorge. "A pornografia 'bizarra' em três variações: a escatologia, o sexo com cigarros e o 'abuso facial'”. In: DÍAZ-BENÍTEZ, María Elvira; FÍGARI, Carlos Eduardo (orgs.). Prazeres dissidentes. Rio de Janeiro: Garamond, 2009. p. 509-536.

. "Labirintos conceituais científicos, nativos e mercadológicos: pornografia com pessoas que transitam entre os gêneros". Cadernos Pagu, Campinas, n. 38, p. 99-128, jun., 2012.

LINDEN, Robin Ruth et al. Against Sadomaschism: a radical feminist analysis. Palo Alto: Frog in the Well, 1982.

MCCLINTOCK, Anne. "Couro imperial: raça, travestismo e o culto da domesticidade". Cadernos Pagu, Campinas, n. 20, p. 7-85, 2003.

MICHA, Ramakas (org.). Tom of Finland: the art of pleasure. Köln: Taschen, 1992.

MORAES, Eliane Robert de. Sade: a felicidade libertina. São Paulo: Arx, 1994.

PIRES, Rogério Brittes W. "Fetichismo religioso, fetichismo da mercadoria, fetichismo sexual: transposic'opes e conexopes". Revista de Antropologia, São Paulo, v. 57, n. 1, p. 347-391, nov. 2014.

PRECIADO, Beatriz. Manifesto contrassexual: práticas subversivas de identidade sexual. São Paulo: n-1 Edições, 2014.

ROST, Mariana. Sexualidades em negociação: a pornografia live streaming no CAM4.com 2016. Dissertação (Mestrado em Ciências Sociais). UNISINOS, São Leopoldo, RS, Brasil.

SARMET, Érica. "Pós-pornô, dissidência sexual e a situación cuir latino-americana: pontos de partida para o debate". Revista Periodicus, Salvador, n. 1, p. 1-19, maio-out., 2014.

SILVA, Marcelle Jacinto da; PAIVA, Antonio Crístian Saraiva. "Pensando corpo, gênero e sexualidade em contexto sado-fetichista". Ponto Urbe, São Paulo, n. 15, p. 2-15, dez., 2014.

STANTON, Eric. Reunion in ropes and other stories. Köln: Taschen, 2001.

WEISS, Margot D. "Working at play: BDSM sexuality in the San Francisco Bay area". Anthropologica, Toronto, n. 48, p. 229-245, jan., 2006.

WILLIE, John. The complete reprint of John Willie's Bizarre. Köln: Taschen, 1995.

ZILLI, Bruno. A perversão domesticada: estudo do discurso de legitimação do BDSM na internet e seu diálogo com a psiquiatria. 2007. Dissertação (Mestrado em Medicina Social), IMS, UFRJ, Rio de Janeiro, RJ, Brasil.

[Recebido em 25/02/2016, reapresentado em $07 / 03 / 2017$ e aprovado em 25/08/2017] 
From excitation to multiplication: sadomasochist and fetishistic images in Bizarre Abstract: This article analyzes the North-American sadomasochist and fetishist magazine Bizarre, edited from 1946 to 1959 by John Willie. We propose a reflection about the interaction between the content of the magazine and its readers, as observed primarily in the the correspondence sections. After a brief introduction about the practices and the network grouped under the acronym $B D S M$, we will search the pages of Bizarre for different modes of agency of images, object and texts, and their effect on bodies, actions and sexual desires usually regarded as 'deviant'. These modes of agency will be divided into excitation, imagination, identification and multiplication, allowing for a discussion with theories about fetishism, the agency of images, and the shaping of sexualized identities.

Keywords: Fetishism; Sadomasochism; Bizarre; Agency; Image.

Rogério Brittes W. Pires (rogeriobwp@gmail.com) é graduado em Ciências Sociais pela FAFICH/UFMG, mestre e doutor pelo Programa de Pós-Graduação em Antropologia Social do Museu Nacional/UFRJ. Empreendeu uma etnografia online e off-line acerca da rede BDSM no Brasil; uma pesquisa teórica acerca do conceito de fetiche em suas múltiplas acepções; e mais recentemente um trabalho de campo entre os businenge (quilombolas) Saamaka, do Suriname 